\title{
Studies in Ethnicity
}

In association with the Social Science Research Council

\section{Editorial board}

Professor Michael Banton, Professor Percy Cohen, Dr Sandra Wallman

'Studies in Ethnicity' emerges out of the work of the Social Science Research Council (S.S.R.C.) Research Unit in Ethnic Relations, whether directly or indirectly. It treats ethnicity as both an empirical and a conceptual problem, reporting new studies in ethnic relations and new approaches to the study of ethnicity.

The first titles in the series are:

Sandra Wallman (ed.): Ethnicity at Work

Verity Saifullah Khan (ed.): Minority Families in Britain 


\section{Ethnicity at Work}

Edited by

Sandra Wallman 
(C) Social Science Research Council 1979

Softcover reprint of the hardcover 1st edition 1979 978-o-333-23511-9

All rights reserved. No part of this publication may be reproduced or transmitted, in any form or by any means, without permission.

First published 1979 by

THE MACMILLAN PRESS LTD

London and Basingstoke

Associated companies in Delhi Dublin

Hong Kong Johannesburg Lagos. Melbourne

New York Singapore and Tokyo

\section{British Library Cataloguing in Publication Data}

Ethnicity at work. - (Studies in ethnicity).

1. Industrial sociology 2. Race awareness

I. Wallman, Sandra II. Series

301.45' 1042 HD6955

ISBN 978-0-333-23512-6 ISBN 978-1-349-16044-o (eBook)

DOI $10.1007 / 978-1-349-16044-0$

This book is sold subject to the standard conditions of the Net Book Agreement.

The paperback edition of this book is sold subject to the condition that it shall not, by way of trade or otherwise, be lent, resold, hired out, or otherwise circulated without the publisher's prior consent in any form of binding or cover other than that in which it is published and without a similar condition including this condition being imposed on the subsequent purchaser. 


\section{Contents}

Notes on Contributors vii

Forewerd ix

Introduction: The Scope for Ethnicity I

SANDRA WALLMAN

I Trading Stereotypes

The case of English Gypsies

JUDITH OKELY

2 Exclusion and Opportunity

Traditions of work amongst British Jews

BARRY KOSMIN

3 Dishwashers and Proprietors

Macedonians in Toronto's restaurant trade HARRY VJEKOSLAV HERMAN

4 Pivots and Presents

Asian brokers in British foundries DENNIS BROOKS and KARAMJIT SINGH

5 Work and Network

South Asian women in South London

VERITY SAIFULLAH KHAN

6 Bureaucracy and Ethnicity

Notions of eligibility to public housing 


\section{Contents}

7 Maoris, Islanders and Europeans

Labour mobility in New Zealand industry JOHN MAGRAE

8 Politics and Business Enterprise

Limits on the scope of ethnicity

DAVID CLARK

9 Controlling the Job

Levels of organisation in casual labour DAVID STYMEIST

10 Circuits of Work

Interdependencies in the urban economy

MILTON SANTOS

Notes and References

Bibliography

Index 


\section{Notes on Contributors}

DENNIS BROOKS is Research Fellow, S.S.R.C. Industrial Relations Research Unit, University of Warwick.

DAVID GLARK is Research Associate in Sociology/Anthropology

(Ethnicity Programme), S.S.R.C. Research Unit in Ethnic

Relations, University of Bristol.

hazel flet is Research Associate in Social Administration

(Housing Programme), S.S.R.C. Research Unit in Ethnic

Relations, University of Bristol.

harry Vjekoslav herman is Assistant Professor of Anthro-

pology, University of Waterloo, Ontario, Canada.

BARR Y KOSMIN is Research Director, Board of Deputies of British

Jews; and Consultant to the Ethnicity Programme, S.S.R.C.

Research Unit in Ethnic Relations, University of Bristol.

JOHN MAGRAE is Senior Lecturer in Economics, University of

Auckland, New Zealand.

JUDITH OKELY is Lecturer in Anthropology, University of

Durham.

verity Saifullah khan is Research Associate in Anthro-

pology (Ethnicity Programme), S.S.R.C. Research Unit in

Ethnic Relations, University of Bristol.

milton santos is Professor of Geography and Architecture,

Edward Larocque Tinker Chair, Columbia University, New York.

KARAMJIT SINGH is Research Associate, S.S.R.C. Industrial

Relations Research Unit, University of Warwick. 
viii Notes on Contributors

DAvid STYmeist is Assistant Professor of Anthropology, University of Manitoba, Winnipeg, Canada.

SANDRA WALLMAN is a social anthropologist, presently Research

Director for the Ethnicity Programme, S.S.R.C. Research

Unit in Ethnic Relations, University of Bristol. 


\section{Foreword}

It is our objective in this volume to throw some light on an important area of practical enquiry. Given this objective it is essential that the central notions ethnicity and work are made plain. The meaning of work is, in these times, variable but not problematic. Ethnicity is more slippery. The reader may be surprised to find the term 'ethnic' applied here to so many different kinds of social grouping, and the term 'ethnicity' used to unite the range of us/them distinctions described in these papers. Some summary points on ethnicity and on its relation to work are therefore in order.

Ethnicity refers generally to the perception of group difference and so to social boundaries between sections of a populacion. In this sense ethnic difference is the recognition of a contrast between 'us' and 'them'. While some analytic attention has been paid to the terms of that contrast - to colour, citizenship, competition and so on as markers of social boundary - too little has been given to the flexibility of that boundary, to contextual shifts in the line between 'us' and 'them', and to the fact that both advantages and disadvantages can accrue from keeping that line intact. We are proposing, therefore, that the value of ethnicity varies. It can be regarded as a resource which will, for some purposes and in some situations, be mobilised to the advantage of a social, cultural or racial category of people; will have no meaning or value at all in other situations; and will, in still others, in which other needs and objectives are paramount, be construed as a liability to be escaped or denied as far as possible.

Ethnicity is not, therefore, the same as culture or 'race'. It is 


\section{x Foreword}

not simply difference: it is the sense of difference which can occur where members of a particular cultural or 'racial' group interact with non-members. Real differences between groups of people are no more (and no less) than potential identity markers for the members of those groups. This potential is taken up and mobilised only where it suits the purposes of a particular encounter. In this volume the encounters at issue all occur in the context of work. Where ethnic differences are used in that context they can be seen to coincide with differences in the way in which work is allocated or organised or experienced-although no priority of ethnicity over work or of work over ethnicity is established: systems of work and of ethnicity feed back on each other in ways which are dependent on the overall logic of the context described.

It follows that ethnicity is not always relevant to social relationships in which people of different 'race' or culture interact; and that when it does count it does not always count in the same way. It is not always the most appropriate principle around which social activity or identity may be organised. In some situations it has so little relevance that participants may simply set it aside, acting without reference to their 'ethnic' affiliations. Where it is imposed on them willy-nilly, or is used in a context for which any of the participants deems it inappropriate, it becomes for them a crippling liability. Since all parties to an encounter do not necessarily want or get the same out of that encounter, the ethnic boundary that constitutes a resource for one party may turn out to be a liability for the other. Ethnicity need not have the same kind of relevance for all the parties involved: the boundary which identifies and includes 'us' also serves to deny and exclude 'them'.

The modern world is fraught with circumstances in which fixed or frozen ethnic boundaries deny people access to particular spheres of power, status or activity - sometimes because they are boxed in by constraints and obligations of the ethnic group to which they belong; more often because they are boxed out of the mainstream by the discriminatory attitudes and practices of ethnic groups to which they do not belong. Racist exclusion, in these terms, is a version of ethnic boundary-keeping which constitutes a fixed liability to the racial minority designated 'out', whatever the advantages expected or gained by those designated 'in'. 
It is important to recognise how difficult it is to observe ethnicity in action. The observer may see a difference between two batches of people which is to him a significant difference. If he then assumes ethnicity to be relevant to all encounters between them, he may seriously misinterpret the meaning or the purpose of events observed. Conversely, but with the same effect, the observed similarity of 'others' does not guarantee their mutuality in any respect. Where similarity and togetherness, difference and differentiation are confused, popular, political or managerial interpretations of conflict and consensus in any context will be wide of the mark.

For all these reasons it is essential that ethnicity be analysed and understood in a context which can itself be delimited. The sphere of work is very well suited to this purpose. In the sphere of work it is possible to identify circumstances in which ethnicity is used as a resource managed for specific occupational goals and in which it is also possible to see ethnicity as a refraction of the cultural traditions and symbolic values by which a particular people defines itself in relation to or by contrast with 'others'. Further, the topic work now has a significance which goes well beyond its relation to pluralism. The availability, experience, organisation and function of work is now changing throughout industrial society and, whether independently or by contagion, in non-industrial settings. The problems created are widely recognised, but still have not been sufficiently clearly defined.

The inter-relation of the two themes allows us to consider the extent to which systems of work are (also) ethnic systems, and to explore the logic of variations in the organisation and experience of work in relation to the marking, maintenance and shifting of that sense of 'us' which is the basis of ethnic identity.

Each of the ten papers which make up this volume constitutes a complete case study of the relation between ethnicity and work. The collection is nevertheless integrated by an introduction which sets out the main themes, and by brief abstracts which are inserted at the beginning of each paper to point out the particular theme or themes illustrated by it and to link it directly to the whole.

The contributors are all professional social scientists, although not all of a single discipline or of a single theoretical or political 


\section{xii Foreword}

persuasion. They are all writing on the basis of their own research and according to their own views of its meaning. All but the last chapter was prepared expressly for this volume, using the framework expressed in its title. None has been published before.

I am indebted to the contributors for allowing their separate efforts to appear in this collective form, for their generous response to my editorial demands and for their tolerance of the generalised interpretation which $I$ have imposed on their material.

Ultimate responsiblity for the volume is of course my own. It does not represent the views of the Social Science Research Council, nor does it necessarily reflect those of all members of the S.S.R.C. Research Unit in Ethnic Relations.

London

S. W.

February 1978 